\title{
A new approach to enzyme histochemical analysis of biopsy specimens
}

\author{
G I MURRAY, S W B EWEN Department of Pathology, University of Aberdeen, Scotland
}

SUMMARY A novel technique combining the freeze drying and embedding in glycol methacrylate at low temperature of tissue permitted the histochemical demonstration of a variety of enzymes, showing maintenance of enzyme activity, accurate enzyme localisation without apparent diffusion, and excellent morphological detail. The results obtained with this new approach were superior to standard techniques used for both enzyme histochemical and morphological studies. Moreover, blocks of the embedded tissue were stored for at least one year at room temperature without loss of enzyme activity. This method should find a wide range of applications in histopathology.

Enzyme histochemistry is an important diagnostic technique which complements standard morphological studies in histopathology. ${ }^{12}$ Usually, cryostat sections of unfixed frozen tissue are necessary for enzyme histochemistry but the use of frozen air dried cryostat sections can result in poor morphological detail compared with conventionally fixed and embedded tissue, and inadequate enzyme localisation. ${ }^{3}$ Long term storage of frozen tissue specimens can also be difficult, requiring a deep freeze operating at $-70^{\circ} \mathrm{C}$, or storage in liquid nitrogen; and damage to tissue can occur when the frozen tissue is removed from storage.

Standard histological processing abolishes the activity of most enzymes and thus it is impossible to correlate accurately morphology with enzyme localisation and activity in the same biopsy specimen. All steps in standard processing procedures, from formalin fixation to wax embedding, contribute to the loss of enzyme activity. ${ }^{4}$ Thus to maintain the activity of most enzymes it is necessary to avoid fixation and wax embedding completely.

Freeze drying is the optimal method of tissue preservation maintaining tissue components in their native state. Conventionally, however, the freeze dried tissue specimens are fixed and embedded in wax after freeze drying. These procedures generally destroy enzyme activity and few enzymes are demonstrable in freeze dried, wax embedded tissue. ${ }^{45}$

Glycol methacrylate resin has been widely used as an alternative embedding medium to wax and the activities of a limited number of enzymes have been

Accepted for publication 2 March 1989 shown in tissue fixed in aldehyde and embedded in resin. ${ }^{6}{ }^{10}$ Enzyme histochemistry performed on these resin sections gives good results with accurate enzyme localisation, high enzyme activity, and excellent morphological detail. These results are achieved by controlled low temperature tissue processing, although only enzymes resistant to fixation can be shown.

We recently developed techniques combining tissue freeze drying with low temperature embedding in glycol methacrylate and showed the preservation of the activities of a variety of dehydrogenases which are sensitive to fixation."

\section{Material and methods}

Fresh tissue samples (muscle, small intestine, and tonsil) were obtained from biopsy specimens submitted to the department of pathology, University of Aberdeen, for diagnostic purposes. Endoscopic and needle biopsy specimens were processed whole; larger specimens were divided into blocks no larger than $1 \times 0.5 \times 0.2 \mathrm{~cm}$. All specimens were rapidly frozen in dichlorodifluoromethane (Arcton 12, ICI plc, London) pre-cooled in liquid nitrogen and freeze dried for 48-96 hours in a tissue freeze drier (Model ETD4, Edwards High Vacuum, Crawley, Sussex) at $-35^{\circ} \mathrm{C}$ under a vacuum of 50 pascals. Water vapour within the vacuum chamber was absorbed with phosphorus pentoxide (BDH Chemicals, Poole, Dorset).

When freeze drying was completed the tissue blocks were inflitrated under vacuum with glycol methacrylate resin monomer ("JB4", Polysciences Ltd, Northampton), containing $0.9 \%$ benzoyl peroxide, for several hours at $-20^{\circ} \mathrm{C}$. The blocks of tissue 


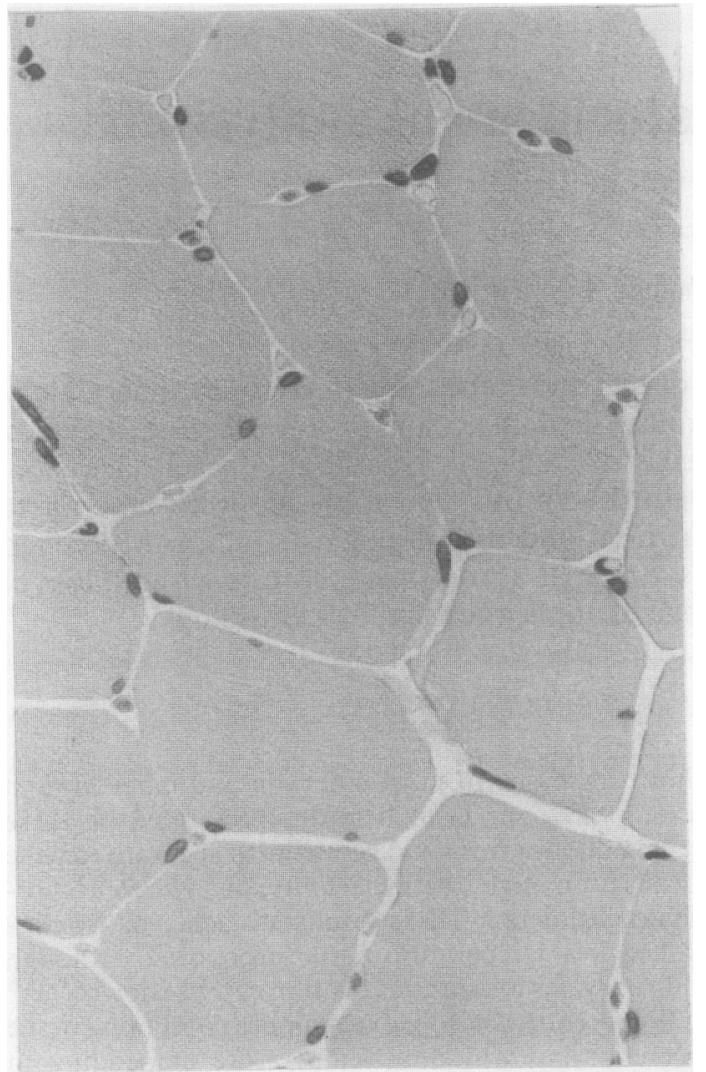

Fig 1 There is excellent morphological preservation of muscle following freeze drying and low temperature glycol methacrylate embedding. (Haematoxylin and eosin.)

impregnated with resin were transferred to embedding moulds, each mould containing $1.25 \mathrm{ml}$ of resin monomer. The resin was chemically polymerised by the addition of $50 \mu \mathrm{l}$ of "JB4 solution B" (Polysciences Ltd, Northampton) per $1.25 \mathrm{ml}$ of resin monomer, the moulds surrounded by crushed ice, placed in a deep freeze $\left(-20^{\circ}\right)$ and the resin allowed to polymerise (usually overnight).

When the resin blocks were polymerised, they were brought to room temperature and $2 \mu \mathrm{m}$ sections prepared using a microtome fitted with a glass knife. The sections were floated out on water, mounted on glass slides, and air dried for 30-60 minutes before use. One section was stained with haematoxylin and eosin for enzyme histochemistry. After initial use blocks of the resin embedded tissue were stored at room temperature.

Alanine 4-methoxy- $\beta$-naphthylamide, diaminobenzidine, 3-(4,5-dimethylthiazol-2yl)-2,5-diphenyl tetrazolium, nicotinamide adenine dinucleotide (NADH), naphthol AS-BI phosphate, napthol AS-TR phosphate and pararosaniline were purchased from
Sigma Chemical Co, Poole, Dorset. Fast Blue B and new fuchsin were obtained from Raymond Lamb, London.

The presence of NADH dehydrogenase was shown using an incubating medium consisting of $2.5 \mathrm{ml}$ of

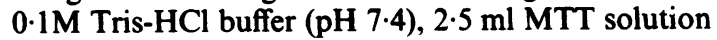
( $2 \mathrm{mg} \mathrm{MTT} / \mathrm{ml}$ distilled water), $1 \mathrm{ml} 5 \mathrm{mM} \mathrm{mag}$ nesium chloride solution, $0.5 \mathrm{ml} 50 \mathrm{mM}$ cobalt chloride solution, $6 \mathrm{mg}$ sodium azide and $20 \mathrm{mg}$ NADH. ${ }^{12}$

Peroxidase activity was localised with an incubating medium of $10 \mathrm{ml} 0 \cdot 1 \mathrm{M}$ Tris- $\mathrm{HCl}$ buffer (pH 7.6), $5 \mathrm{mg}$ diaminobenzidine, and $0.2 \mathrm{ml} 1 \%$ hydrogen peroxide. $^{3}$

Acid phosphatase activity was shown with an incubating solution consisting of $5 \mathrm{ml} 0 \cdot 1 \mathrm{M}$ acetate buffer (pH 5.0), $12 \mathrm{ml}$ distilled water, $5 \mathrm{mg}$ naphthol AS-BI phosphate and $1.6 \mathrm{ml}$ freshly prepared hexazotised pararosaniline. The $\mathrm{pH}$ of the final incubating medium was adjusted to 5 with $1.0 \mathrm{M}$ sodium hydroxide. ${ }^{13}$ Alkaline phosphatase activity was localised using an incubating medium consisting of $10 \mathrm{ml}$

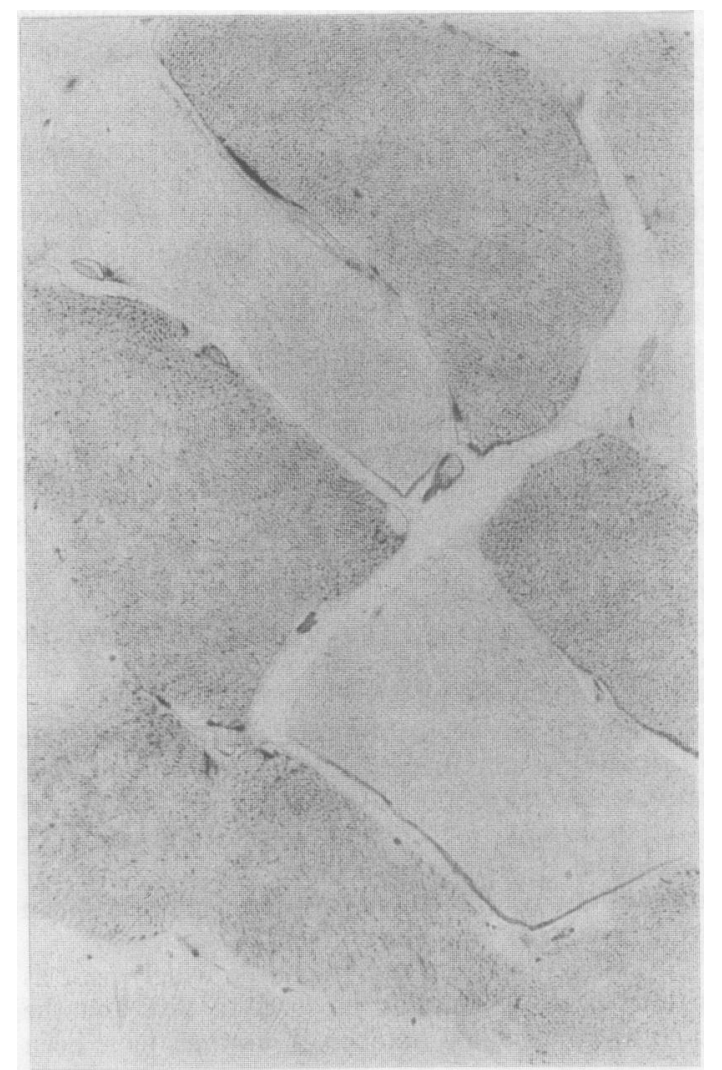

Fig 2 NADH dehydrogenase activity is present in type 1 muscle fibres of a freeze dried resin embedded muscle biopsy specimen. 


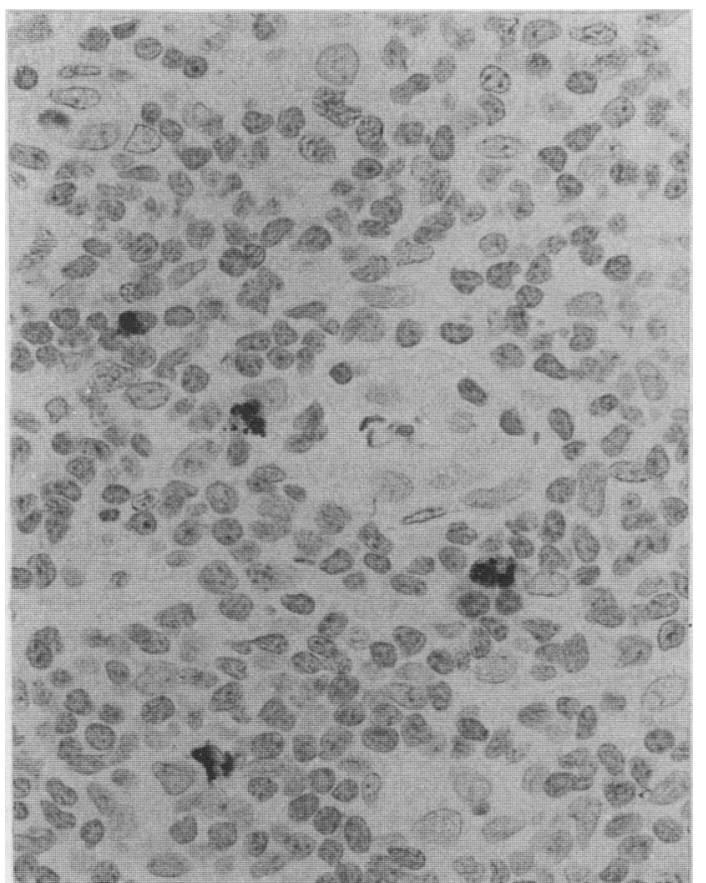

Fig 3 Peroxidase activity is present in mast cells of freeze dried plastic embedded tonsil.

$0.05 \mathrm{M}$ Tris- $\mathrm{HCl}$ buffer (pH 8.6), $5 \mathrm{mg}$ naphthol ASTR phosphate, and $50 \mu \mathrm{l}$ of freshly prepared hexazotised new fuchsin. ${ }^{13}$

The activity of aminopeptidase $M$ was shown using an incubating solution consisting of $5 \mathrm{ml} 0 \cdot 1 \mathrm{M}$ phosphate buffer (pH 7.0), $3 \mathrm{mg}$ alanine 4-methoxy- $\beta$ naphthylamide, and $5 \mathrm{mg}$ Fast Blue B. ${ }^{14}$

All the enzyme histochemical reactions were performed at $37^{\circ} \mathrm{C}$ and when the reactions were complete the slides were washed in water, counterstained with haematoxylin or methyl green, air dried and mounted in DPX (BDH Chemicals, Poole, Dorset) or glycerine jelly.

\section{Results}

Sections of the freeze dried tissue embedded in resin displayed excellent morphological detail superior to that obtained with conventionally processed, formalin fixed, wax embedded tissue and unfixed cryostat sections (fig 1).

A variety of enzymes, which can be studied histochemically and are useful diagnostically, were readily shown using standard techniques on plastic sections (figs 2-6). All the enzymes studied were accurately localised without diffusion and each enzyme showed high activity. NADH dehydrogenase activity was present in type 1 muscle fibres and columnar absorptive epithelial cells of small intestinal villi. Alkaline phosphatase was localised to the brush border of small intestinal villi and vascular endothelium. Activity of acid phosphatase was present in macrophages. Peroxidase activity was observed in some mast cells and red blood cells. Aminopeptidase $\mathbf{M}$ was localised to the brush border of small intestinal villi. Control sections incubated without substrate displayed an absence of non-specific staining of the tissue or resin.

Blocks of the processed tissue have been stored at room temperature for at least one year without apparent loss of enzyme activity.

\section{Discussion}

The activity of several hydrolytic enzymes have been shown in tissue fixed in aldehyde and embedded in glycol methacrylate. ${ }^{6}$ Fixation has a variable inhibitory effect on enzyme activity, however, with some groups of enzymes such as the dehydrogenases being very sensitive to fixation, and often fresh unfixed cryostat sections of tissue must be used for enzyme histochemistry. ${ }^{4}$

Freeze drying is a method of tissue preservation in which tissue blocks are rapidly frozen at very low

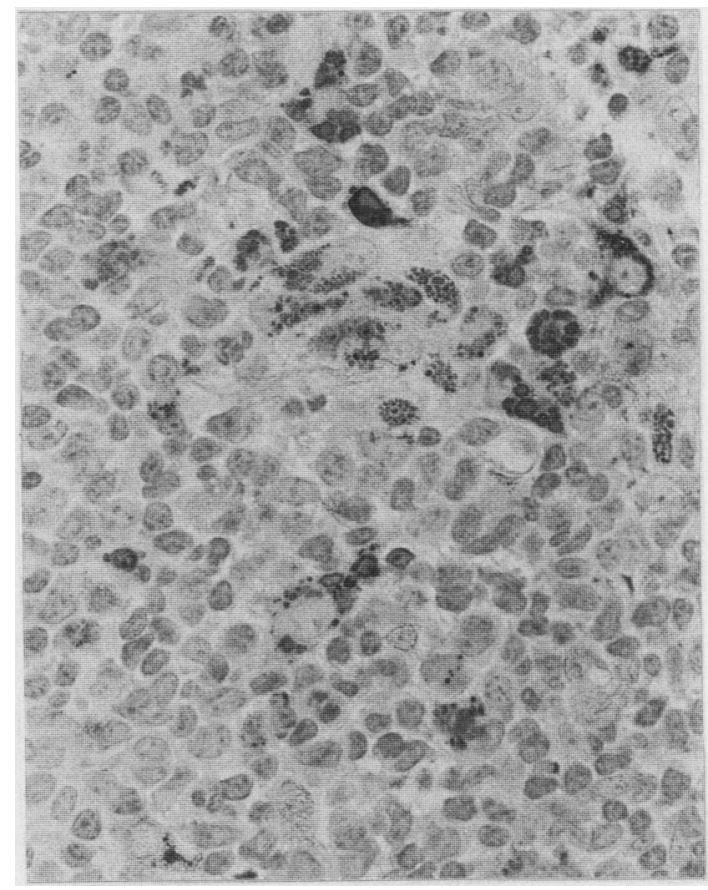

Fig 4 Acid phosphatase activity is shown in macrophages of tonsil processed as fig 3. There is a granular localisation of the final reaction product with no diffusion of the final reaction product. 


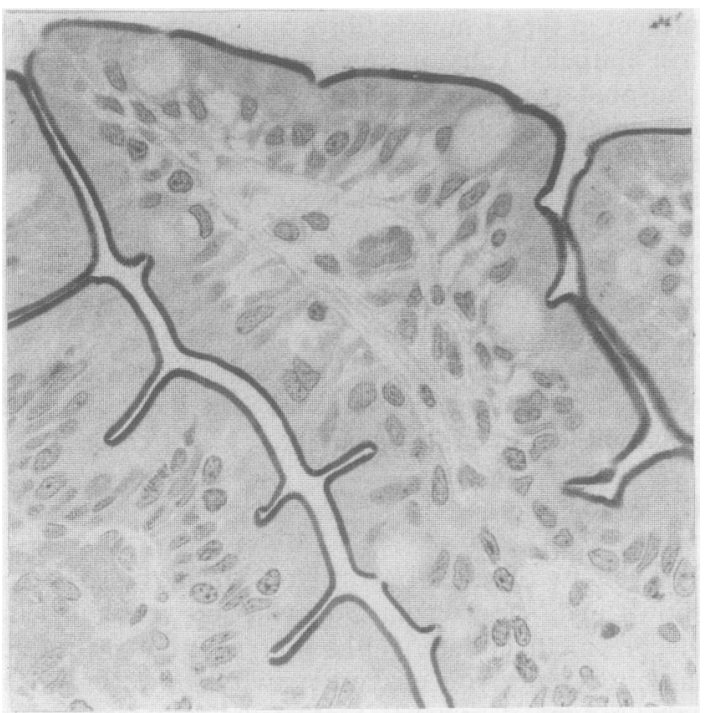

Fig 5 Alkaline phosphatase activity is accurately localised to the brush border of villi of a freeze dried plastic embedded duodenal biopsy specimen.

temperature, then water is removed under vacuum while the tissue is kept frozen so that the components are retained in a reactive state. Conventionally, freeze drying is followed by some form of heat generated vapour fixation and embedding. These processes abolish the activity of most enzymes and only a few hydrolytic enzymes are demonstrable in freeze dried wax embedded tissue. ${ }^{515}$

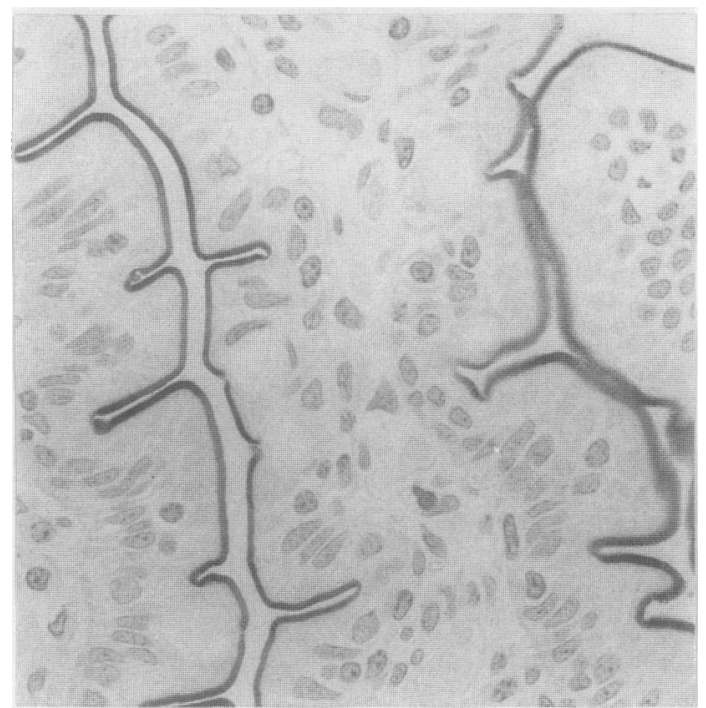

Fig 6 Aminopeptidase $M$ activity is demonstrable in the brush border of villi of a freeze dried duodenal biopsy specimen embedded in resin.
Embedding the freeze dried tissue directly in glycol methacrylate resin at low temperature avoids the toxic effects of hot molten wax and as the resin physically stabilises the tissue blocks, there is no requirement for any form of fixation. " The sections of processed tissue can be reacted directly in the appropriate histochemical media without any pre-treatment. Accurate enzyme localisation was achieved without the use of special techniques to minimise diffusion which are often applied to unfixed cryostat sections to obtain optimal enzyme localisation. ${ }^{16}{ }^{17}$ Enzyme localisation and morphological detail were readily correlated in the plastic sections.

This technique represents an important advance in enzyme histochemistry and plastic embedding is now the method of choice for enzyme histochemistry. ${ }^{18}$ Freeze drying and resin embedding should find wide application in histopathology as the reactivity of cryostat sections is combined with the superior morphological detail of fixed, embedded tissue. This method is particularly well suited to processing needle and endoscopic biopsy specimens in which the amount of diagnostic information obtained from a small biopsy specimen must be maximised. Moreover, pathologists will have embedded tissue available, for retrospective correlative studies.

This work was supported by grants from The Scottish Hospital Endowment Research Trust and Grampian Health Board. The technical assistance of $\mathrm{Mr} G$ McHardy and Mr A McKinnon and the typing by Mrs I Watson are gratefully acknowledged.

\section{References}

1 Filipe MI, Lake BD. Histochemistry in pathology. Edinburgh: Churchill Livingstone, 1983.

2 Lojda $Z$. The importance of protease histochemistry in pathology. Histochem J 1985;17:1063-89.

3 Pearse AGE. Histochemistry. Theoretical and applied. Vol 2. 3rd ed. Edinburgh: Churchill Livingstone, 1972.

4 Pearse AGE. Histochemistry. Theoretical and applied. Vol 1. 4th ed. New York: Churchill Livingstone, 1980.

5 Burstone MS. A method of freeze-drying and its use in histochemistry and pathology. JNCI 1956;17:49-64.

6 Litwin JA. Light microscopic histochemistry on plastic sections. Prog Histochem Cytochem 1985;16:1-84.

7 Islam A, Henderson ES. Glycol methacrylate embedding for light microscopy. 1. Enzyme histochemistry on semithin sections of undecalcified marrow cores. J Clin Pathol 1987;40:1 194-200.

8 Cohen MB, Miller TR, Beckstead JH. Enzyme histochemistry and thyroid neoplasia. Am J Clin Pathol 1986;85:668-73.

9 Cohen MB, Beckstead JH, Ferrell LD, Benedict Yen TS. Enzyme histochemistry of hepatocellular neoplasms. Am J Surg Pathol 1986;10:789-94.

10 Beckstead JH, Halverson PS, Ries CA, Bainton DF. Enzyme histochemistry and immunohistochemistry on biopsy specimens of pathologic human bone marrow. Blood 1981;57:1088-98.

11 Murray GI, Burke MD, Ewen SWB. Dehydrogenase enzyme 
histochemistry on freeze-dried or fixed resin embedded tissue. Histochem J 1988;20:491-8.

12 Murray GI, Burke MD, Ewen SWB. Enzyme histochemical demonstration of NADH dehydrogenase on resin-embedded tissue. J Histochem Cytochem 1988;36:815-19.

13 Pearse AGE. Histochemistry. Theoretical and applied. Vol 1. 3rd ed. London: Churchill Livingstone, 1968.

14 Gossrau R. Investigation of proteinases in the digestive tract using 4-methoxy-2-naphthylamine (MNA) substrates. $J$ Histochem Cytochem 1981;29:464-80.

15 Burstone MS. Histochemical comparison of naphthol AS-phosphates for the demonstration of phosphatases. JNCI 1958; 20:601-15.
16 Meijer AEFH. Semipermeable membranes for improving the histochemical demonstration of enzyme activities in tissue sections. III. Lactate dehydrogenase. Histochemie 1973; 35:165-72.

17 Butcher RG. Tissue stabilisation during histochemical reactions: the use of collagen polypeptides. Histochemie 1971;28:231-5.

18 Murray GI. Is wax on the wane? J Pathol 1988;156:187-8.

Requests for reprints to: Dr G I Murray, Department of Pathology, University of Aberdeen, Foresterhill, Aberdeen AB9 2ZD, Scotland. 